\title{
DOMINASI PARADIGMA FIKIH DALAM PERIWAYATAN DAN KODIFIKASI HADIS
}

\author{
Rifqi Muhammad Fatkhi \\ Sekolah Pascasarjana UIN Syarif Hidayatullah Jakarta \\ Jl. Kertamukti, Pisangan, Ciputat Timur, Tangerang Selatan, Banten \\ E-mail: rifqimuhammad@uinjkt.ac.id
}

\begin{abstract}
Domination of the Figh Paradigm in Hadith Transmission and Codification. This paper primarily argues that figh has been dominating the transmission and canonization of $\underline{H}$ aditts since the early Islamic period. The fiqh orientation in the transmission of $\underline{H} a d i t s$ that has occurred since the early Islamic period, the formalization of figh schools, and the mainstreaming of fiqh in $\underline{H}$ adits works are the reasons that made it dominant. Moreover, the formation and acceptance of al-Kutub al-Sittah was also to pursue fiqh interests, rather than just the already important matter of $\underline{H}$ adîts codification.
\end{abstract}

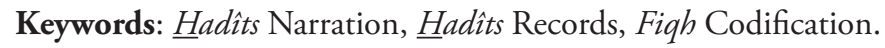

\begin{abstract}
Abstrak: Dominasi Paradigma Fikih dalam Periwayatan dan Kodifikasi Hadis. Artikel ini utamanya menyatakan bahwa fikih telah mendominasi periwayatan dan pembukuan Hadis sejak periode awal Islam. Orientasi fikih pada periwayatan dan kodifikasi Hadis, formalisasi madrasah fikih, dan pengarusutamaan fikih pada karya-karya Hadis, adalah bukti-bukti yang menunjukkan fikih mendominasi periwayatan dan kodifikasi Hadis. Fakta lainnya adalah, pembentukan al-Kutub al-Sittah dan aspek penerimaannya ternyata lebih menunjukkan alasan pemenuhan kepentingan fikih ketimbang hanya periwayatan dan kodifikasi Hadis semata.
\end{abstract}

Kata Kunci: Periwayatan Hadis, Pembukuan Hadis, Dominasi Fikih.

\section{Pendahuluan}

Jonathan Brown dalam disertasinya menyimpulkan bahwa kitab Hadis karya al-Bukhârî dan Muslim sejak awal merupakan cerminan konstruksi identitas Sunnî, khususnya di kalangan sarjana Muslim yang berafiliasi mazhab pada al-Syâfi'î dan dimulai secara terbatas oleh jaringan murid-murid al-Syafi î̀ dan Ah̆mad ibn Hanbal. Kedua kelompok ini sepakat bahwa al-Shahbih $\underline{a y n}$ sebagai dasar untuk mengenali aturan hukum (fikih) otentik dari Nabi. Kesepakatan ini kemudian diikuti oleh mazhab lain sebagai alat ukur otentisitas dan otoritas sumber hukum. Belakangan, bahkan kelompok Hanafî menyatakan al-Shahîhaynn sebagai bahasa umum kalangan Sunnî ketika membicarakan Hadis. ${ }^{1}$ Jauh sebelum Brown, Joseph Schacht lebih awal menelisik bahwa periwayatan Hadis pada awalnya adalah untuk kepentingan legitimasi hukum dan karenanya tidak

Received: 23rd January 2012, Revised: 16th May 2012, Accepted: 30th May 2012.

1 Jonathan Brown, The Canonization of al-Bukhârî and Muslim: The Formation and Function of the Sunnî Hadìth Canon, (Leiden: Brill, 2007), h. 365. otentik alias fabrikasi periwayat Hadis jauh setelah Nabi Muhammad wafat. ${ }^{2}$ Kedua sarjana Barat tersebut terlihat memiliki kesamaan pandangan bahwa periwayatan dan pembukuan Hadis lebih didominasi oleh kepentingan fikih, bukan pada periwayatan Hadis semata.

Jauh sebelum al-Bukhârî dan Muslim, sebenarnya geliat untuk membukukan (kodifikasi) Hadis menurut fakta sejarah telah ada sejak masa sahabat. 'Umar ibn al-Khaththâb $(23 \mathrm{H})$ misalnya, pernah berpikir untuk membukukan Hadis. Setelah meminta pendapat dari sahabat yang lain yang kemudian mendapatkan dukungan untuk membukukan Hadis, Umar kemudian ber-istikhârah sebulan lamanya, dan ia mendapatkan petunjuk untuk membatalkan rencananya. ${ }^{3} \mathrm{Hal}$ ini dapat ditelusuri melalui surat-surat sahabat kepada sahabat yang lain yang berisi Hadis-hadis Rasulullah, maupun catatan-catatan pribadi sahabat yang kemudian dikenal dengan istilah shahîffah.

\footnotetext{
${ }^{2}$ Joseph Schacht, The Origins of Muhammadan Jurisprudence, (Oxford: Oxford University Press, 1979), h. 160.

${ }^{3}$ Muhammad 'Ajjâj al-Khathîb, Ushûl al- $\underline{\text { Hadîts }}$ Ulûmuh wa Mushthalahuh, (Bayrût: Dâr al-Fikr, 1989), h. 154.
} 
Penelitian mengenai perkembangan penulisan Hadis dalam proses panjang Hadis dalam khazanah Islam, telah dilakukan oleh para ulama maupun sarjana belakangan. Beberapa di antaranya dapat disebut misalnya, Fî Rihâb al-Sunnah al-Kutub al-Shihâha alSittah karya Muhammad Muhammad Abû Syuhbah, ${ }^{4}$ Manâhij al-Muhadditsîn karya Muhammad Mubârak al-Sayyid, Tadwîn al-Sunnah al-Nabawîyyah Nasy'atuh wa Tathawwuruh min al-Qarn al-Awwal ilâ Nihâyah alQarn al-Tâsi' al-Hijrî karya Muhammad ibn Mathar al-

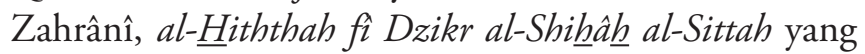
ditulis oleh al-Qanûjî (1307 H). Tulisan lain berkenaan dengan studi kitab Hadis adalah Studi Kitab Hadis yang disusun oleh beberapa dosen Tafsir Hadis Fakultas Ushuluddin Institut Agama Islam Negeri (sekarang Universitas Islam Negeri) Sunan Kalijaga Yogyakarta.

Berbeda dengan tulisan-tulisan yang tersebut di atas, penelitian ini tidak memusatkan perhatian pada kajian metode kitab-kitab Hadis, khususnya al-Kutub alSittah. Tulisan ini menjelaskan faktor-faktor pembentuk dominasi fikih dalam periwayatan dan pembukuan Hadis tersebut, diawali dengan memaparkan konsensus mayoritas umat Islam generasi awal terhadap kitabkitab Hadis yang dijadikan pegangan umat Islam dalam Hadis. Selanjutnya, tulisan ini akan melihat akar orientasi fikih dalam periwayatan Hadis sejak masa sahabat, pengaruh formalisasi madrasah fikih pada penulisan Hadis, dan dominasi fikih yang menjadi arus utama penulisan kitab Hadis.

\section{Konsensus Ulama terhadap Kitab Hadis Fikih}

Hampir seluruh ulama sepakat atas lima kitab Hadis yang ada di dalam al-Kutub al-Sittah, perbedaan pendapat terjadi pada masalah kitab Hadis yang dianggap lebih layak ditempatkan sebagai kitab keenam dalam al-Kutub al-Sittah. Mayoritas ulama Hadis sepakat untuk menempatkan kitab Hadis karya Ibn Mâjah yang dikenal dengan Sunan ibn Mâjah sebagai kitab keenam, dan orang yang pertama kali memasukkan Sunan ibn Mâjah ke dalam al-Kutub al-Sittah adalah Abû al-Fadhl Muhammad ibn Thâhir al-Maqdisî (507 H). Ibn Thâhir al-Maqdisî memasukkannya dengan cara mengumpulkan athrâf Sunan ibn Mâjah ke dalam karyanya tentang kumpulan athraf kitab Hadis yang berjudul Athrâf al-Kutub al-Sittah dan menyebut Ibn Mâjah dalam Syurûth al-A'immat al-Sittah, sebuah buku kecil yang ia tulis untuk menjelaskan tentang syaratsyarat penerimaan Hadis keenam penyusun kitab Hadis

\footnotetext{
${ }^{4}$ Muhammad Muhammad Abû Syuhbah, Fî Rihâab al-Sunnah al-Kutub al-Shihâh al al-Sittah, (Al-Qâhirah: Majma' al-Buhûts alIslâmîyyah, 1995).
}

\section{dalam al-Kutub al-Sittah. ${ }^{5}$}

Sepakat dengan Ibn Thâhir al-Maqdisî, ahli Hadis setelahnya seperti Ibn 'Asâkir $(571 \mathrm{H})$ menulis kitab Athrâf al-Sunan al-Arba'ah dan kitab kumpulan guruguru enam imam Hadis yang berjudul al-Mujjam alMusnad dengan menyebut Ibn Mâjah sebagai imam keenam di dalamnya. Setelah Ibn 'Asâkir ada 'Abd al-Ghanî al-Maqdisî $(600 \mathrm{H})$ yang menyusun para periwayat Hadis dalam enam kitab Hadis yang berjudul al-Kamâl fì Asmâ' al-Rijâl, kemudian diikuti oleh Jamâl al-Dîn Yûsuf al-Mizî $(742 \mathrm{H})$ dengan Tuhfat al-Asyrâf dan Tahdzîb al-Kamâl fì Asmầ al-Rijâl. ${ }^{6}$

Berbeda dengan Ibn Thâhir al-Maqdisî dan

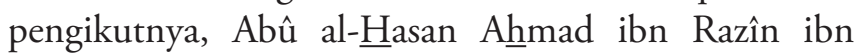
Mu âwiyah al-'Abdarî $(535 \mathrm{H})$ dalam karyanya Tajrîd al-Shihâh $\underline{\text { w }}$ wa al-Sunan yang kemudian disepakati oleh Abû al-Sa âdât Majd al-Dîn Ibn al-Atsîr $(606$ H) dalam Jâmi“ al-Ushûlnya memilih kitab Hadis lain. Keduanya menyebut kitab al-Muwaththa' karya al-Imām Mâlik lebih layak dianggap sebagai kitab keenam. Menurut Ibn al-Atsîr, al-Kutub al-Sittah adalah al-Muwaththa, Shabîh al-Bukhârî, Shahîh Muslim, Sunan Abî Dâwûd, Sunan at-Tirmidzî, dan Sunan an-Nasầî. Menurutnya, penyusun al-Muwaththa' bahkan harus didahulukan bahkan dari pada al-Bukhârî dan Muslim dengan pertimbangan senioritas Mâlik dan bahwa ia adalah gurunya para imam Hadis. ${ }^{7}$ Sedangkan Ibn al-Shalâh $(643 \mathrm{H})$, tokoh yang dianggap otoritatif dan menjadi referensi dalam ilmu Hadis, hanya menganggap lima kitab Hadis saja sebagai kitab Hadis standar dengan sebutan al-Kutub al-Khamsah. Demikian pula halnya dengan Muhy al-Dîn Yahyâ ibn Syaraf al-Nawâwî $(676 \mathrm{H})$ yang kemudian diamini oleh 'Alầ al-Dîn Mughulathâya $(762$ H), dan Shalâh al-Dîn al-'Alầîyang lebih memilih untuk menjadikan Musnad al-Dârimî atau yang lebih dikenal dengan Sunan al-Dârimî sebagai kitab keenam dalam al-Kutub al-Sittah. ${ }^{8}$

\footnotetext{
${ }^{5}$ Pada buku yang disebut terakhir ini, Ibn Thâhir al-Maqdisî tidak secara jelas menyebutkan syarat-syarat yang ditetapkan Ibn Mâjah dalam menyusun kitab hadisnya, berbeda dengan kelima imam yang lainnya. Abû al-Fadhl Muhammad ibn Thâhir al-Maqdisî, Syurûth alA'immat al-Sittah (Bayrût: Dâr al-Kutub al-'Ilmîyah, 1984), h. 24.

${ }^{6}$ Syams al-Dîn Abu al-Khayr Muhammad ibn 'Abd al-Rahmân

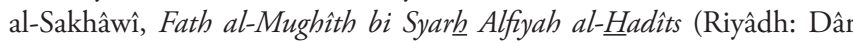
al-Minhâj, 2007), Cet. I, tahqị̂: 'Abd al-Karîm al-Khudhayr dan Muhammad ibn Fuhayd Ali Fuhayd, Jilid I, h. 156; Ja’far al-Kattânî, al-Risâlah al-Mustathrafah li Bayân Masyhûr Kutub al-Sunnat alMusyarrafah (Bayrût: Dâr al-Kutub al-'Arabîyah, 1995), Cet. I, tahqqiq: Abû 'Abd al-Rahmân Shalâh Muhammad 'Awîdhah, h. 18 .

${ }^{7}$ Majd al-Dîn Abû al-Sa'âdât al-Mubârak ibn Muhammad ibn alAtsîr al-Jazarî, Jâmi' al-Ushûl fî Ahâadîts al-Rasûl, tahqîq: 'Abd al-Qâdir

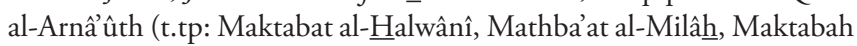
Dâr al-Bayân, 1969), Jilid I, h. 179. Syams al-Dîn al-Sakhâwî, Fath al-Mughith bi Syarh Alfyah al-Hadîts, Jilid I, h. 156.

${ }^{8} \mathrm{Ibn}$ al-Shalâh al-Syahrâzûrî, Muqaddimah ibn al-Shalâh fî̀ ulûm
} 
Betapa pun perbedaan pendapat tentang kitab Hadis yang dijadikan sebagai kitab Hadis standar, kitab Hadis yang ditawarkan oleh masing-masing tokoh adalah kitab-kitab Hadis yang kental dengan nuansa fikih di dalamnya. Penerimaan mayoritas ulama dengan mengamini tesis Ibn Thâhir al-Maqdisî yang menginisiasi Sunan Ibn Mâjah menjadi salah satu bagian dari al-Kutub al-Sittah menunjukkan bahwa konsensus kitab Hadis fikih sekaligus aspek penerimaannya lebih didasari pada pemenuhan kepentingan fikih.

\section{Melacak Akar Orientasi Fikih dalam Periwayatan Hadis}

Penerimaan enam kitab Hadis sebagai kitab Hadis standar yang diakui oleh mayoritas ulama bahkan umat Islam secara umum, selain karena faktor standar kesahihan yang ditetapkan oleh masing-masing penulis, dan oleh karenanya kualitas status Hadis-hadis yang terdapat di dalamnya, juga ditengarai karena adanya hegemoni paradigma orientasi fikih yang muncul sejak masa sahabat dan terus eksis bahkan hingga saat ini.

Pada awalnya, kitab Hadis yang diakui oleh ulama dan dikenal sebagai kitab standar Hadis hanya empat yang kemudian dikenal dengan istilah al-Kutub alArba'ah. ${ }^{9}$ Jumlah kitab ini kemudian bertambah menjadi lima kitab dan dikenal dengan istilah alKutub al-Khamsah yaitu lima kitab Hadis yang terdiri atas: al-Jâmi' al-Shahîh al-Musnad al-Mukhtashar min Umûr Rasûl Allâh shallâ Allâh 'alyh wa sallam wa Sunanih wa Ayyâmi ${ }^{10}{ }^{10}$ arya al-Bukhârî yang kemudian dikenal dengan sebutan Shahîh $\underline{h}$ al-Bukhârî, al-Musnad al-Shabîh al-Mukhtashar min al-Sunan bi al-Naql Adl 'an al-'Adl 'an Rasûl Allâh karya Muslim atau Shabîh $\underline{b}$

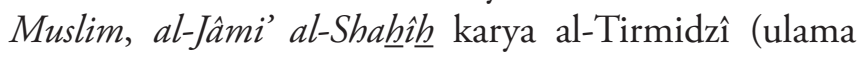
juga menyebutnya dengan nama Sunan al-Tirmidzî), al-Sunan karya Abû Dâwûd, dan al-Mujtabâ atau alSunan al-Shaghîr karya al-Nasâî yang kemudian dikenal dengan Sunan al-Nasẩî.

Kelima kitab Hadis tersebut dipilih oleh ulama Hadis sebagai kitab standar dalam Hadis, bahkan kelima penyusunnya dianggap sebagai lima tokoh Hadis yang dijadikan referensi utama dalam kajian Hadis yang kemudian dikenal dengan istilah alA'immat al-Khamsah. Pilihan kepada kelima kitab ini

al-hadîts, (Bayrût: Dâr al-Kutub al-'Ilmîyah, 1995), h. 37-38; Ja'far alKattânî, ar-Risâlah al-Mustathrafah, h. 18.

${ }^{9}$ Ibn Thâhir al-Maqdisî, Syurûth al-A'immat al-Sittah, h. 24.

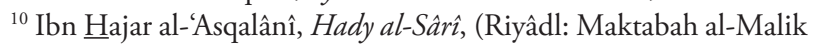
Fahd al-Wathanîyah Atsnâ' al-Nasyr, 2001), h. 8. Berbeda dengan Ibn Hajar, menurut Ibn al-Shalâh nama asli kitab Hadis karya al-Bukhârî adalah al-Jâmi al-Musnad al-Shahîh al-Mukhtashar min Umûr Rasûl Allâh shallâ Allâh 'alayh wa sallam wa Sunanih wa Ayyâmih. Ibn alShalâh, Muqaddimah, h. 29. didasari pada beberapa hal, di antaranya adalah Hadishadis yang dimuatnya secara umun memiliki kualitas shahîh (meskipun di dalamnya terdapat sejumlah Hadis dengan kualitas hasan dan dhaif), dan keunggulan pada sistematika penyusunan kelimanya berdasarkan orientasi fikih.

Al-Bukhârî misalnya, dalam menyusun kitab Hadisnya selain memasukkan Hadis-hadis yang menurutnya shahîh —meski di dalamnya juga terdapat Hadis mu'allaq, mawqûf, fatwa sahabat dan tâbi în, juga dinilai memfokuskan karyanya pada pengambilan hukum atau istinbâth al-ahkâm meski terdapat juga sejarah dan tafsir di dalamnya, sehingga kemudian Ibn Hajar menginisiasi istilah fiqh al-Bukhârî fì tarâjumih sebagai penegas orientasi fikih yang ditempuh oleh al-Bukhârî. Demikian pula halnya, metode yang dilakukan oleh Muslim meskipun dinilai lebih memberikan perhatian pada aspek sanad sebagaimana yang dinyatakan oleh al-Hâazimî $(594 \mathrm{H})$, namun terlihat dengan jelas dalam kitab Hadisnya sistematika yang disusun berdasarkan tema-tema fikih untuk kepentingan pengambilan hukum fikih, bahkan ulama maghribî memberikan perhatian khusus kepada kitab Hadis yang ditulisnya. ${ }^{11}$

Orientasi yang sama juga dapat dilihat pada tiga kitab Hadis berikutnya yaitu karya Abû Dâwûd, al-Tirmidzî, dan al-Nasầî, bahkan dalam beberapa kesempatan Abû Dâwûd sengaja meringkas riwayat Hadis yang panjang dengan alasan kepentingan fikih yang ia tuju. AlGhazâlî bahkan menganggap kitab Sunan Abî Dâwûd sebagai referensi utama dalam berijtihad. ${ }^{12}$ Sedangkan al-Tirmidzî dan al-Nasầî diakui dapat menggabungkan dua kecenderungan perhatian dalam penulisan Hadis, yaitu Hadis dan fikih (al-shinâa at al-hadîtsîyah wa alfiqhîyah). Secara sederhana al-Suyûthî menyimpulkan bahwa Shahîh al-Bukhârî diperuntukkan bagi orang yang ingin memperdalam ilmu agama atau tafaqquh, Sunan Abî Dâwîd pada pemahaman Hadis-hadis yang memiliki muatan hukum, Jâmi' al-Tirmidzî pada kompilasi Hadis dan fikih, dan demikian pula halnya

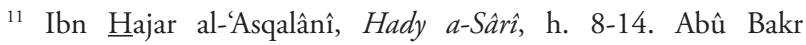
Muhammad ibn Mûsâ al-Hâzimî, Syurûth A'immat al-Khamsah (Bayrût: Dâr al-Kutub al-'Ilmîyah, 1984), Cet. I, h. 68. Abû Zahww, Al- Hadîts wa al-Munadditsûn, (Riyâdl: al-Ri'âsah al-Tsaqâfah li Idârât fî al-Buhûts al-'Ilmîyah wa al-Iftâ wa al-Da’wah wa al-Irsyâd, 1984), h. 380-381. Abû al-Thayyib al-Sayyid Shiddîq Hasan Khân al-Qinnawjî,

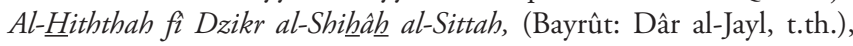

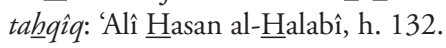

${ }_{12}$ Muhammad ibn Mathar al-Zahrânî, Tadwîn al-Sunnah alNabawîyah, Tadwînal-Sunnah al-Nabawîyah Nasy'atuhwa Tathawwuruh min al-Qarn al-Awwal ilâ Nihâyah al-Qarn al-Tâsi' al-Hijrî, Madinah: Dâr al-Khudlayrî, 1998), h. 150. Abû Hâmid al-Ghazâlî, al-Mustashfâ min 'Ilm al-Ushûl, (Bayrût: Dâr al-Fikr, t.th.), Jilid II, h. 351. 


\section{dengan Sunan al-Nasầi. ${ }^{13}$}

Abû Dâwûd, misalnya, perhatiannya pada fikih ditunjukkan dengan perhatiannya pada penjelasannya atas pengamalan Hadis yang dilakukan oleh para sahabat dan tâbi'in, aplikatif atau tidaknya sebuah Hadis, aplikasi Hadis pada sebuah wilayah teritorial, dan memberi fatwa pada masalah-masalah fikih. Sedangkan al-Tirmidzî, selain menunjukkan kecenderungannya terhadap fikih dengan pembuatan judul (tarjamah) pada setiap bab pencantuman Hadis, ia bahkan lebih memperkuat dengan menjelaskan pengamalan sebuah Hadis yang dilakukan oleh ulama, mendeskripsikan pendapat beberapa mazhab fikih dan men-tarjîhnya, serta memunculkan masalah-masalah hukum yang terkandung di dalam sebuah Hadis yang ia riwayatkan. ${ }^{14}$

Kecenderungan orientasi fikih yang terlihat pada kelima kitab Hadis tersebut, ternyata telah ada sejak abad I H bahkan sejak masa sahabat, namun dalam format yang berbeda, yaitu dalam hal periwayatan Hadis. Sepeninggal Rasulullah, para sahabat pada saat itu yang dipelopori oleh Abû Bakr $(13 \mathrm{H})$ dan 'Umar $(23 \mathrm{H})$ sangat berhati-hati dalam meriwayatkan Hadis, bahkan keduanya melarang para sahabat untuk meriwayatkan Hadis. ${ }^{15}$ Mereka hanya meriwayatkan Hadis yang berkenaan dengan masalah-masalah fatwa yang berkenaan dengan permasalahan domestik rumah tangga yang diperoleh dari istri-isteri Rasulullah misalnya, dan keputusan-keputusan yang berkenaan dengan hukum. Oleh karenanya, kecenderungan orientasi fikih dalam meriwayatkan Hadis tersebut juga menjadi salah satu faktor yang mendasari para sahabat dalam berijtihad. ${ }^{16}$

Sikap demikian ditempuh oleh sahabat dalam rangka menutup rapat peluang bagi orang-orang munafik yang muncul ke permukaan untuk memanfaatkan Hadis atau bahkan memalsukan Hadis sesuai dengan kemauan dan tujuan mereka. Sahabat-sahabat yang memiliki banyak riwayat Hadis seperti Abû Bakr, 'Imrân ibn Hushayn (52 H), Abû 'Ubaydah al-Jarrâh $(18 \mathrm{H})$, dan al-Abbâs ibn 'Abd al-Muththalib $(32 \mathrm{H})$ pada saat itu hanya sedikit meriwayatkan Hadis. Sa'îd ibn Zayd $(50 \mathrm{H})$ bahkan hanya meriwayatkan dua Hadis sedangkan Ubay ibn 'Imârah al-Anshârî satu Hadis saja. Bahkan sahabat

\footnotetext{
${ }^{13}$ Jalâl al-Dîn al-Suyuthî, Tadrîb al-Râwî fî Syarh Taqrîb al-Nawawî (Bayrût: Dâr al-Kutub al-'Ilmîyah, 1996), Cet. I, ta’lîq: Abû 'Abd alRahmân ibn Muhammad ibn 'Awîdhah, Jilid I, h. 87-88.

${ }^{14}$ Hasan Fawzî Hasan al-Shaî̀û̀, Al-Manhaj al-Naqdî 'ind alMutaqaddimîn min al-Muhadditsîn wa Athar Tabâyun al-Manhaj (Tesis: Jâmi'ah 'Ayn Syams, 2000), h. 427-431.

15 Muhammad al-Hudharî Bik, Târîkh al-Tasyrî̀ al-Islâmî (Indonesia: Dâr Ihyâ̂ al-Kutub al-'Arabîyah, 1981), Cet. VII, h. 108109.

${ }^{16}$ Muhammad al-Hudharî, Târî̀h al-Tasyrî̀ al-Islâmî, h. 114-115.
}

yang secara personal dekat dengan Rasulullah seperti Abû Hurayrah pada masa kekhalifahan Abû Bakr dan 'Umar membatasi dirinya untuk meriwayatkan Hadis. ${ }^{17}$

Periwayatan Hadis yang dilakukan oleh sahabat yang membatasi hanya pada masalah-masalah hukum dan fatwa tersebut selain ditempuh untuk menutup rapat peluang orang-orang munafik, juga dilakukan dengan tujuan menjaga kelestarian Alquran agar tidak tercampur dengan riwayat Hadis, dan kekhawatiran sahabat seperti Anas ibn Mâlik (92 H) dan Zayd ibn Arqâm (68 $\mathrm{H})$ dari melakukan kesengajaan meriwayatkan sebuah riwayat yang ternyata bukan berasal dari Rasulullah. ${ }^{18}$ Beberapa fakta sejarah tersebut setidaknya membuktikan beberapa hal yang menunjukkan bahwa pada masa sahabat khususnya pada pemerintahan Abû Bakr dan 'Umar mulai menampilkan kecenderungan periwayatan Hadis pada masalah-masalah yang berkenaan dengan fatwa dan hukum yang keduanya masuk dalam ranah fikih, meskipun hanya berdasarkan pada alasan-alasan yang kondisional, mulai dari tindakan preventif terhadap orang-orang munafik, hingga kehati-hatian para sahabat dalam meriwayatkan Hadis.

Meskipun demikian halnya kecenderungan orientasi fikih yang ada pada masa sahabat, perhatian beberapa sahabat dalam upaya melakukan dokumentasi Hadis tidak seluruhnya menemukan bentuknya sebagaimana kecenderungan yang ada. Perhatian tersebut diwujudkan dalam bentuk catatan kecil berupa surat antar sahabat maupun tulisan dalam beberapa lembaran yang kemudian dikenal dengan istilah shahîffah seperti catatan yang berisi Hadis Rasulullah dan keputusankeputusan Abû Bakr, 'Umar, dan 'Utsmân ibn 'Affân $(35 \mathrm{H})$ yang ditulis oleh Asîd ibn $\underline{\text { Hudhayr al-Anshârî }}$ $(20 \mathrm{H})$ kepada Marwân ibn al- Hakam $(65 \mathrm{H})$ tentang pencurian, ${ }^{19}$ surat Jâbir ibn 'Abd Allâh $(78 \mathrm{H})$ kepada 'Amir ibn Sa'd ibn Abî Waqqâsh (104 H), surat Zayd ibn Arqam al-Anshârî (68 H) kepada Anas ibn Mâlik $(92 \mathrm{H}),{ }^{20}$ surat Zayd ibn Tsâbit $(45 \mathrm{H})$ tentang $\underline{\text { had }}$ kepada 'Umar, surat Samurat ibn Jundub (58 H) kepada anaknya Sulaymân, ${ }^{21}$ dan surat 'Abd Allâh ibn Abî Awfâ

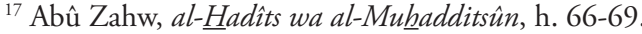

18 Abû Zahw, al-Hadîts wa al-Muhadditsûn, h. 67. Mushthafâ al-Sibầî, al-Sunnah wa Makânatuhâ fî̀ al-Tasyrî̀ al-Islâmî (Bayrût: Al-Maktab al-Islâmî Dâr al-Warrâq li al-Nasyr wa al-Tawzî, t.th.), h. 79-80.

${ }^{19}$ Ahmad ibn Hanbal, al-Musnad, Jilid XIV, (al-Qâhirah: Dâr alHadîts, 1995), 28, No. Hadis 17909-17911.

${ }^{20}$ Jamâl al-Dîn Abû al-Hajjâij Yûsuf al-Mizî, Tahdzîb al-Kamâl fî Asmâ al-Rijâl (Bayrût: Muassasah al-Risalah, 1983), Cet. I, tahqị̂: Basyâr 'Awwâd Ma’rûf, Jilid X, h. 10.

${ }^{21}$ Ibn Sîrîn bahkan memberikan apresiasi terhadap surat ini dengan pernyataannya bahwa surat yang ditulis oleh Samurah kepada anaknya berisi ilmu yang banyak. Ibn Hajar al-'Asqalânî, Tahdzîb al-Tahdzîb (Bayrût: Muassasah al-Risâlah, 1995), Jilid II, h. 116.
} 
(86 H) kepada Sâlim Abû al-Nadhr $(129 \mathrm{H}){ }^{22}$

Sementara dokumentasi Hadis yang dilakukan oleh para sahabat dalam bentuk shabîffah di antaranya adalah shahîffah yang ditulis oleh Abû Bakr, 'Alî ibn Abî Thâlib, 'Abd Allâh ibn 'Amr ibn al-'Ash $(65 \mathrm{H})$ yang kemudian dikenal dengan sebutan al-Shahîfah al-Shâdiqah, dan 'Abd Allâh ibn Abî Awfâ, Abû Mûsâ al-Asy'arî $(50 \mathrm{H})$, Jâbir ibn 'Abd Allâh (78 H), dan ㅌammâm (106 H) yang merupakan riwayat Hadis dari Abû Hurayrah sejumlah 138 Hadis yang kemudian dikenal dengan sebutan al-Shahîffah al-Shahîh $\underline{h} a h{ }^{23}$

\section{Formalisasi Madrasah Fikih}

Kecenderungan orientasi fikih yang ada pada masa sahabat sebagaimana tersebut di atas, berlanjut bahkan pada taraf formalisasi yang ditandai dengan terbentuknya dua "sekolah" utama dalam fikih di Madinah tempat tinggal mayoritas sahabat dan sebagai pusat pemerintahan Islam sampai pada masa khilafah 'Utsman, dan di Kufah yang dijadikan sebagai pusat pemerintahan Islam oleh 'Alî ibn Abî Thâlib pada masa kekhalifahannya, dan juga tempat menetap sejumlah sahabat baik dari kalangan Muhâjirîn maupun Anshâr. Kedua madrasah ini kemudian lebih dikenal dengan sebutan Madrasah al- $\underline{H} i j a ̂ z$ untuk Madinah dan Madrasah al-'Irâq untuk Kûfah. ${ }^{24}$

Faktor penyebab lahirnya kedua madrasah tersebut di antaranya adalah ekspansi Islam ke beberapa wilayah di luar Madinah dan Mekah yang juga menyebabkan penyebaran para sahabat ke wilayah-wilayah yang ditaklukkan guna menjadi wakil khalifah sekaligus juru dakwah dan guru para tâbi'in di masing-masing wilayah tersebut. Beberapa sahabat yang menjadi rujukan Hadis dan fikih di Madinah misalnya Abû Bakr, 'Umar dan puteranya 'Abd Allâh $(73 \mathrm{H})$, 'Alî ibn Abî Thâlib (sebelum kepindahannya ke Kufah), 'A'isyah $(57 \mathrm{H})$, Abû Hurayrah $(58 \mathrm{H})$, Abû Sa îd al-Khudrî, dan Zayd ibn Tsâbit $(45$ H). Sedangkan beberapa tâbi' in yang tercatat menjadi murid-murid mereka diantaranya adalah Sa îd ibn al-Musayyib (94 H), 'Urwah ibn al-Zubayr ibn al-'Awwâm al-Asadî (94 H), Abû Bakr ibn 'Abd al-Rahmân al-Makhzûmî (94 H), 'Alî ibn al-Husayn ibn 'Alî ibn Abî Thâlib (94 H), 'Ubayd Allâh ibn 'Abd Allâh ibn 'Utbah ibn Mas'ûd (98 H), Sâlim ibn 'Abd Allâh ibn 'Umar (106 H), Sulayman ibn Yasâr (107 H), al-Qâsim ibn Muhammad ibn Abî

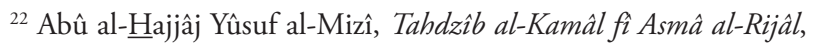
Jilid X, h. 128, dan Jilid XIV, h. 318. Muhammad ibn Mathar alZahrânî, Tadwîn al-Sunnah al-Nabawîyah, h. 86-90.

${ }^{23}$ Ibrâhîm Fawzî, The Documentation of Sunnah and Hadits (London: Riad el-Rayyes Books Ltd., 1995), Cet. II, h. 47. Muhammad ibn Mathar al-Zahrânî, Tadwîn al-Sunnah al-Nabawîyah, h. 91-92.

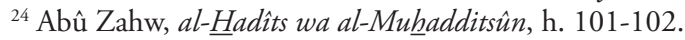

Bakr (107 H), Nâfi' (117 H), Muhammad ibn Muslim yang dikenal dengan nama Ibn Syihâb al-Zuhrî (124 H), dan Abû al-Zinâd 'Abd Allâh ibn Dhakwân (131 H). Beberapa di antara tâbi' in di Madinah bahkan dikenal dengan istilah al-Fuqahâ al-Sab'ah yaitu Sa'îd ibn al-Musayyib, 'Urwah ibn al-Zubayr, al-Qâsim ibn Muhammad ibn Abî Bakr, Khârijah ibn Zayd, Abû Bakr ibn 'Abd al-Rahmân ibn Hârits ibn Hisyâm, Sulaymân ibn Yasâr, dan 'Ubaydillâh ibn 'Utbah ibn Mas'ûd. ${ }^{25}$ Beberapa catatan sejarah menjelaskan bahwa setelah perang Hunayn, tersisa bersama Rasulullah sejumlah 12.000 sahabat yang 10.000 orang sahabat menetap di Madinah, sedangkan 2000 orang lainnya tersebar di luar Madinah. ${ }^{26}$

Adapun di wilayah Mekah beberapa sahabat yang tercatat menjadi guru di antaranya adalah Muâdz ibn Jabal $(17 \mathrm{H})$ yang sengaja ditinggalkan pasca fath Makkah, 'Abd Allâh ibn al-Sầib al-Makhzûmî (73 $\mathrm{H})$, 'Attâb ibn Asîd $(23 \mathrm{H})$, al- $\underline{\mathrm{H}}$ akam ibn Abî al'Ash, 'Utsmân ibn Thalhah $(42 \mathrm{H})$, dan 'Abd Allâh ibn 'Abbâs $(68 \mathrm{H})$ setelah kepulangannya dari Basrah yang kepadanya berguru sejumlah tâbi' in besar seperti 'Ikrimah $(107 \mathrm{H})$ pembantunya sendiri, Mujâhid ibn

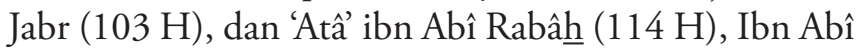
Mulaykah $(119 \mathrm{H})$, serta 'Amr ibn Dînâr $(126 \mathrm{H}) .{ }^{27}$

Kedua kota tersebut menjadi tempat tujuan para pencari ilmu dari segala penjuru baik dari generasi sahabat maupun tabi'in khususnya Madinah yang menjadi pusat pemerintahan Islam selama periode kekhalifahan Abû Bakr, 'Umar, dan 'Utsmân ibn 'Affân. Ibadah haji dan umrah menjadi salah satu faktor pendorong mereka untuk berkunjung ke kedua kota tersebut, sehingga pada saat itu Mekah dan Madinah menjadi pusat studi tempat berkumpulnya para pencari ilmu dan periwayat Hadis, tentunya saat berkumpul, mereka saling berbagi ilmu dan riwayat Hadis atau sekedar melakukan verifikasi atas riwayat yang mereka terima di tempat tinggal mereka masing-masing.

Pusat studi lain yang terbentuk pada masa sahabat adalah Kufah. Ibrâhîm al-Nakha î (96 H) menyebutkan setidaknya ada 300 orang sahabat yang ikut dalam bay'at al-'aqabah dan sekitar 70 orang sahabat pejuang perang Badar menetap di kota ini. Beberapa sahabat seperti 'Alî ibn Abî Thâlib, 'Abd Allâh ibn Masûd (32 H), Salmân al-Fârisî (35 H), ㅂudzayfah ibn al-Yamân

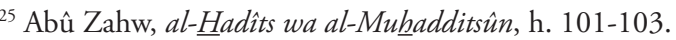

${ }^{26}$ Muhammad al-Khudharî Bik, Târîkh al-Tasyrî̀ al-Islâmî, (Bayrût: Dâr al-Kutub al-'Ilmîyah, 1994), Cet. II, h. 97-102. Abû Ishhâq alSyîrâzî, Thabaqât al-Fuqahầ (Bayrût: Dâr al-Rầid al-'Arabî, 1970),

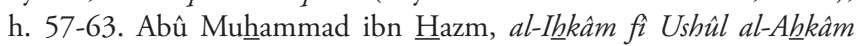
(Mishr: Mathba'ah al-'Ashimah, t.th.), Jilid II, h. 240.

${ }^{27}$ Abû Ishhâq al-Syîrâzî, Thabaqât al-Fuqahâ', h. 69-70. Abû Zahw, al-Hadîts wa al-Muhadditsûn, h. 103-104. 
(36 H), 'Ammâr ibn Yâsir (37 H), Khabbâb ibn al-Aratt (37 H), Abû Mûsâ al-Asy'arî (42 H), al-Mughîrah ibn Syu 'bah $(50 \mathrm{H})$, al-Nu'mân ibn Basyîr $(64 \mathrm{H})$, 'Alqamah ibn Qays al-Nakha'î (62 H), Masrûq ibn al-Ajda' alHamadânî (63 H), dan Anas ibn Mâlik al-Anshârî (94 $\mathrm{H})$ tinggal di kota ini. Sedangkan beberapa tokoh dari generasi tabi' in di antaranya adalah Masrûq ibn al-Ajda' al-Hamadânî (63 H), 'Ubaydah ibn 'Amr al-Sulmânî al-Murâdî (92 H), al-Aswad ibn Yazîd al-Nakha’î (95 H), Syurayh ibn al- Hârits $(82 \mathrm{H})$, Ibrâhîm ibn Yazîd al-Nakhâi (95 H), Sâîd ibn Jubayr (95 H), 'Amir ibn Syarâhîl al-Sya'bî (104 H), Abû al-'Aliyah Rafî̀ ibn

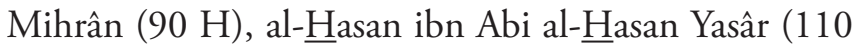
H), Abû al-Sya'tsâ’ Jâbir ibn Zayd (93 H), Muhammad ibn Sîrîn $(110 \mathrm{H})$, dan Qatâdah ibn Di' âmah al-Dawsî $(118 \mathrm{H}){ }^{28}$

Meskipun demikian terpusatnya dua wilayah studi, kondisi tersebut tidak membatasi para tabi'in untuk hanya meriwayatkan Hadis dari para sahabat yang berada satu wilayah dengan mereka. Sejarah mencatat aktifitas periwayatan Hadis mereka yang kemudian dikenal dengan istilah al-riblah fì thalab al- $\underline{h}$ aditts yang menunjukkan perjalanan studi lintas wilayah tersebut. Para tabi'in di Iraq misalnya, menyempatkan waktu mereka untuk mengunjungi dan berguru kepada para sahabat di Madinah seperti 'Alqamah ibn Qays al-Nakhaî mengunjungi 'Umar, 'Utsmân, dan 'Alî.. Masrûq ibn al-Ajda' al-Hamadânî dan al-Aswad ibn Yazîd selain menemui 'Umar dan 'Alî juga berguru kepada 'A'iSyah, ibn Mas'ûd, Ubay ibn Ka'b, Muâdz, dan ibn 'Umar. Saî̀d ibn Jubayr berguru kepada ibn 'Abbâs dan ibn 'Umar. ${ }^{30}$

Terbentuknya kedua madrasah fikih sebagaimana tersebutdiatas, semakin menegaskan indikasidimulainya pengarusutamaan fikih dalam periwayatan Hadis, karena perjalanan studi lintas wilayah yang dilakukan oleh sekelompok tabi'in lebih didasari semangat meriwayatkan Hadis dalam bingkai mempelajari dasar hukum atas persoalan yang mereka hadapi daripada sekedar mengoleksi riwayat-riwayat Hadis.

\section{Pengarusutamaan Fikih dalam Kodifikasi Hadis}

Secara garis besar, pola penyusunan kitab Hadis

${ }^{28}$ Abû Zahw, al $\underline{\text { H}}$ adîts wa al-Muhadditsîn, h. 104. Muhammad al-Khudharî Bik, Târîkh al-TaSyrî̀ al-Islâmî, h. 103-105. Abû Ishhâq al-Syîrâzî, Thabaqât al-Fuqahầ, h. 79-80. Muhammad al-Khudharî Bik, Târîkh al-Tasyrî̀ al-Islâmî, h. 103-106.

${ }^{29}$ Al-Dzahabî, Siyar A'lâm al-Nubalâ', (Bayrût: Mu’assasah alRisâlah, t.th.), J. IV, 53-61.

${ }^{30}$ Al-Dzahabî, Tadzhîb Tahdzîb al-Kamâl fì Asmầ al-Rijal (Cairo: Al-Fâzûq al-Hadîtsîyah li al-Thibâah wa al-Nasyr, 2004), Cet. I, Jilid VIII, h. 419-420, Jilid I, h. 389-390, Jilid III, h. 422, dan Jilid V, h. 26-30. yang berkembang pada kurun waktu abad II H sampai dengan abad IV $\mathrm{H}$ dapat dipolakan menjadi empat bentuk metode penulisan kitab Hadis, yaitu: sunan, mushannaf, jâmi, dan musnad. Tiga model yang pertama pada hakikatnya berada pada wilayah yang sama yaitu mengakomodasi kepentingan fikih yang memang menjadi kebutuhan dan lebih dapat diterima masyarakat Islam pada umumnya. ${ }^{31}$ Munculnya kitabkitab Hadis yang bercorak fiqhî mulai abad II H yang kemudian dikenal dengan sebutan sunan menjadi pertanda menguatnya pengarusutamaan fikih yang terjadi di kalangan masyarakat Islam pada saat itu. AlKattânî menyebutkan bahwa sunan adalah kitab Hadis yang disusun berdasarkan urutan tema-tema fikih dan (secara umum karena faktanya, terdapat beberapa Hadis yang dinilai mawqûf di dalam kitab-kitab sunan) tidak memuat riwayat-riwayat yang dinilai mawqûf. ${ }^{32}$

Sedangkan pada abad III H khususnya, secara umum menurut Abû Zahw pola penyusunan kitabkitab Hadis yang lahir berada pada salah satu dari tiga pola berikut: Pertama, kitab Hadis yang ditulis dalam bingkai memberikan argumentasi dan atau bantahan

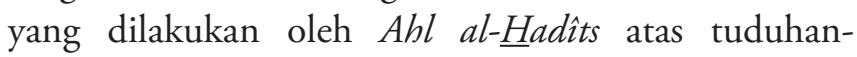
tuduhan $A$ hl al-Ra'y baik yang berkenaan dengan para periwayat Hadis maupun beberapa Hadis yang dianggap sulit untuk diterima atau bahkan bertentangan satu sama lain. Salah satu tokoh Hadis yang terlibat dalam masalah ini adalah Ibn Qutaybah yang menulis sebuah

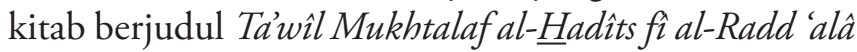
A'dầ' al- $\underline{\text { Hadîts. }} .{ }^{33}$

Pola kedua adalah koleksi Hadis-hadis berdasarkan nama-nama sahabat yang meriwayatkannya tanpa memperhatikan nilai Hadis yang dicantumkan, atau tema-tema yang terkandung di dalamnya, yang dikenal dengan istilah musnad, seperti: Musnad Abî Dâwûd alThayâlisî al-Bashrî (204 H), Musnad Asad ibn Mûsâ alUmawî al-Mishrî $(212 \mathrm{H})$ yang dikenal dengan nama: Asad al-Sunnah, Musnad 'Ubayd Allâh ibn Mûsâ al-Kûfî̀ (213 H), Musnad Abî Ishbâq ibn Nashr ibn Ibrâhîm alMuthawwî̀ (213 H), Musnad Abî Bakr Abd Allâh ibn

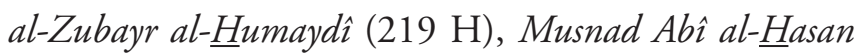
Musaddad al-Bashrî (221 H), Musnad Yahyâ ibn 'Abd alHamî̀ al-Kûfî (228 H), Musnad Abî Jấfar al-Musnadî

${ }^{31}$ Model sunan (dan mushannaf) adalah pola penulisan kitab Hadis yang disusun berdasarkan tema-tema fikih dan untuk kepentingan pengambilan hukum (istinbâth al-ậkâm), adapun jâmi' adalah kitab hadis yang disusun dengan memuat setidaknya delapan pembahasan, yaitu 'aqẩid, 'ibâdah, mu'âmalah, siyar, manâqib, raqầiq, fitan, dan akhbâr yawm al-Qiyâmah, sedangkan musnad adalah kitab Hadis yang disusun berdasarkan urut nama sahabat yang meriwayatkan. Lihat Mahmûd al-Thuhhân, Taysîr Mushthala $\underline{h}$ al- $\underline{\text { H}}$ adîts (Kuwait: Markaz al-Hudâ li al-Dirâsât, 1984), Cet. VII, h. 131-132.

${ }^{32}$ Ja'far al-Kattânî, al-Risâlah al-Mustathrafah, h. 33.

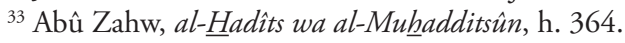


(229 H), Musnad Abî Bakr ibn Abî Syaybah (235 H), Musnad Ishhâaq ibn Ibrâhîm ibn Râhuwayh $(238 \mathrm{H})$, Musnad 'Utsmân ibn Abî Syaybah (239 H), Musnad

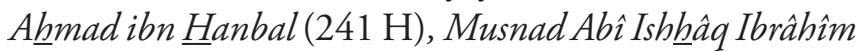
ibn Sa'd al-Thabarî al-Baghdâdî (249 H), Musnad Abd Allâh ibn Humayd (249 H), Musnad Abî Yáqûb Ishhâaq ibn Bublûl al-'Anbarî (252 H), Musnad Ya'qûb ibn Syaybah (262 H), Musnad Mubammad ibn Mahdî̀ (272 H), Musnad al-Bâqî ibn Mukhallad al-Qurthubî (276 H). ${ }^{34}$

Pola ketiga adalah beberapa kitab Hadis yang disusun dengan pola penyusunan sunan. Selain empat kitab sunan (al-Kutub al-Arba'ah, jika karya al-Tirmidzî dianggap sebagai sunan) dalam al-Kutub al-Sittah, kitab-kitab Hadis lain yang memiliki pola yang sama di antaranya adalah: Sunan al-Syâfî̀ riwayat Abû Ibrâhîm Ismầîl ibn Yahyâ al-Muznî, Abû al-Walìd 'Abd al-Mâlik ibn 'Abd al-'Azîz ibn Jurayj al-Rûmî (151 H), Sunan Husyaym ibn Basyîr $(183 \mathrm{H})$ gurunya Ahmad ibn

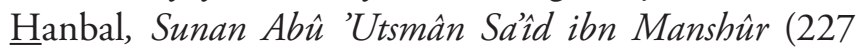

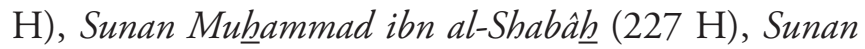
Abî Qurrah Mûsầ ibn Thâriq al-Yamânî al-Zabîdî̀ (227 H), Sunan Abî Amr Sabl ibn Abî Sabl (240 H), Sunan

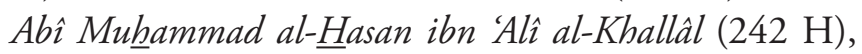
Sunan al-Dârimî (255 H), Sunan Ab̂̀ Bakr Abmad ibn

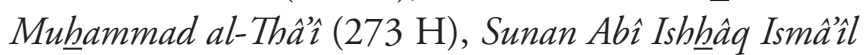
al-Azdî al-Bashrî (282 H), Sunan Ab̂̀ Muslim Ibrâhîm al-Bashrî al-Kajjî (292 H), Sunan Abî Muhammad Yûsuf ibn Yảqûb al-Azdî al-Bashrî (297 H).

Sedangkan koleksi kitab Hadis dengan model sunan yang dilahirkan pada abad IV $\mathrm{H}$ dan $\mathrm{V} \mathrm{H}$ di antaran-

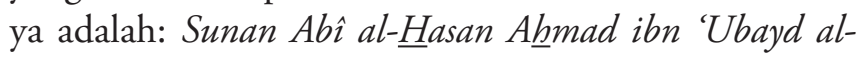
Bashrî (341 H), Sunan Abî Bakr Munhammad ibn Yahyâa al-Hamdânî (347 H), Sunan Abî Bakr Abmad ibn Sulaymân al-Najjâd al-Baghdâdî (348 H), Sunan 'Alî ibn 'Umar al-Dâraquthnî (385 H), Sunan Ibn Lâl Abî Bakr

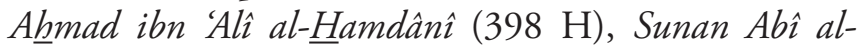
Qâsim Hibat Allâh ibn al-Hasan al-Thabarî $(418 \mathrm{H})$,

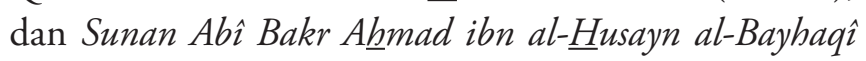
$(458 \mathrm{H}) .^{35}$

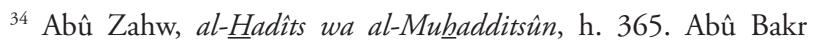

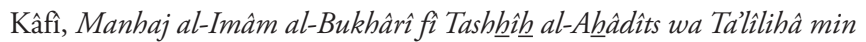

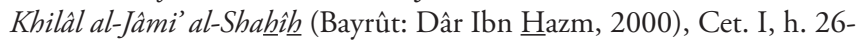
27. Muhammad ibn Muhammad Abû Syuhbah, al-Wasîth fî̀ 'Ulûm wa

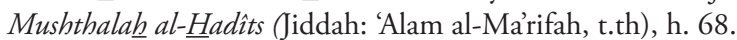

${ }^{35}$ Ja’far al-Kattânî, al-Risâlah al-Mustathrafah, h. 33-37. Sa’d ibn 'Abd Allâh, Manâhij al-Muhadditsîn, h. 68. Ibn al-'Imâd Syihâb alDîn Abû al-Falâh 'Abd al-Hayy ibn Ahmad alSyadzarât al-Dzahab fî Akhbâr Man Dzahab (Bayrût: Dâr Ibn Katsîr, 1986), Cet. I, tahqqîq: 'Abd al-Qâdir al-Arnầ ûth dan Mahmûd alArnẩûth, Jilid III, h. 126-127, 192, 245, 334, 387, 414. Ja'far alKattânî, al-Risâlah al-Mustathrafah, h. 33-37. Ibn al-'Imâd, Syadzarât al-Dzahab fì Akhbâr Man Dzahab, Jilid IV, h. 222, 251-254, 453-455, 514; Jilid V, h. 92-93, 248-250.
Selain beberapa kitab Hadis yang disebut dengan kitab sunan, pola penyusunan yang identik dengan pengarusutamaan fikih dalam pembukuan Hadis adalah kitab-kitab Hadis yang dikenal dengan istilah mushannaf dan jâmî. Beberapa kitab Hadis dengan pola susunan jâmi ‘selain karya al-Bukhârî, Muslim, dan al-Tirmidzî yang dilahirkan pada kurun waktu abad II sampai dengan abad IV H di antaranya adalah: Jâmi' Abî̀ 'Urwah Màmar ibn Râsyid al-Bashrî (153 H), Jâmi' Abî 'Abd Allâh Sufyân ibn Saî̀ ibn Masrûq al-Tsawrî $(161 \mathrm{H})$, Jâmi' Abî Muhammad Sufyân ibn 'Uyaynah (198 H), dan Jâmi' Abî Bakr Abmad ibn Mubammad al-Khallâl al-Hanbalî $(311 \mathrm{H}){ }^{36}$

Adapun kitab Hadis dalam bentuk mushannaf yang lahir pada abad II H di antaranya adalah: Mushannaf Abî Muhammad 'Abd al-Malik ibn 'Abd 'Azîz ibn Jurayj $(150 \mathrm{H})$, Mushannaf Muhammad ibn Ish $\underline{h} a q$ ibn Yasâr al-Mathlabî (151 H), Mushannaf Saî̀ ibn Abî 'Arûbah (156 H), Mushannaf Abî Amr Abd al-Rahmân ibn Amr al-Awzầi (156 H), Mushannaf Muhammad ibn 'Abd alRahmân ibn Abî Dzi'b (158 H), Mushannafal-Rabî'ibn Shabîh al-Bashrî (160 H), Mushannaf Syu'bah ibn alHajjâj $(160 \mathrm{H})$, Mushannaf al-Layts ibn Sa'd al-Fahmî (175 H), Mushannaf Abî Sufyân Wakî̀ ibn al-Jarrâh alRu'âsî (197 H), Mushannaf Abî Salamah Hammâd ibn Salamah al-Rib'i (167 H), Mushannaf 'Abd Allâh ibn alMubârak $(181 \mathrm{H})$, Mushannaf Jarîr ibn 'Abd al- $\underline{\text { Hamidd }}$ al-Dhabî $(188 \mathrm{H})$, al-Atsâr li Muhammad ibn al-Hiasan al-Syaybânî (189 H), Mushannaf Abd Allâh ibn Wahb al-Mishrî $(197 \mathrm{H}){ }^{37}$ Sedangkan karya-karya kumpulan Hadis dalam bentuk mushannaf yang dilahirkan pada abad III Hijryah di antaranya adalah: Mushannaf $A b \hat{\imath}$ al-Rabî̀ Sulaymân ibn Dâwûd al-Zahrânî $(234 \mathrm{H})$, Mushannaf Abî Bakr 'Abd Allâh ibn Mubammad ibn Abî Syaybah (235 H), Mushannaf Abî Bakr 'Abd al-Razzâq ibn Hammâm al-Shan'ânî (211 H), dan Mushannaf Baqî ibn Mukhallad al-Qurthubî $(276 \mathrm{H}) .^{38}$

Selain dalam bentuk jâmi' dan mushannaf, beberapa ulama juga menyusun kitab Hadisnya dalam format bab fikih namun tidak menyebut langsung dengan penamaan jâmi' atau mushannaf, seperti: Kitâb al-Atsâr

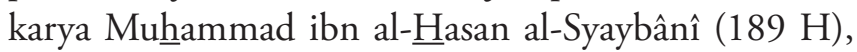

${ }^{36}$ Istilah sunan dan mushannaf menurut Sa'd ibn 'Abd Allâh adalah sama, lihat Sa'd ibn 'Abd Allâh, Manâhij al-Muhadditsîn, h. 68; Ja'far al-Kattânî, al-Risâlah al-Mustathrafah, h. 40.

${ }^{37}$ Al-Hasan ibn 'Abd al-Rahmân al-Râmahurmuzî, al-Muhaddits al-Fâshil bayn al-Râwî wa al-Wầ̂ (Bayrût: Dâr al-Fikr, 1971), Cet. I, tahqqîq: Muhammad 'Ajjâj al-Khathîb, h. 611-620. Ja’far al-Kattânî, alRisâlah al-Mustathrafah, h. 39.

${ }^{38}$ Abû Zahw, al-Hiadîts wa al-Muhadditsûn, h. 287-301. Ja'far alKattânî, al-Risâlah al-Mustathrafah, h. 40. Muhammad ibn Mathar alZahrânî, Tadwîn al-Sunnah al-Nabawaîyah, h. 103-105. Ibn al-'Imâd, Syadzarât al-Dzahab fî Akhbâr Man Dzahab, Jilid II, h. 226-228, 235, dan 244. 
al-Umm karya al-Syâfi'î, Tahdzîb al-Atsâr karya Abû Ja 'far Muhammad ibn Yazîd al-Thabarî (310 H), Syarh Ma ânîal-Atsâr karya Abû Ja far Aḥmad ibn Muhammad al-Thahâwî $(321 \mathrm{H})$, dan Kitâb al-Syarî‘ah fí al-Sunnah

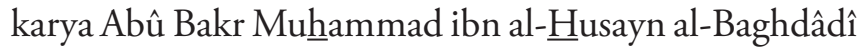
al-Ajurrî $(360 \mathrm{H}) .{ }^{39}$

Selain itu, ada juga ulama yang menyusun kitab Hadis dengan tema-tema tertentu dalam fikih seperi bersuci, salat, puasa, dan lain sebagainya. Beberapa diantaranya adalah al-Thahûr karya Abû 'Ubayd alQâsim ibn Sallâm al-Syâfiî (224 H) dan Abû Dâwûd al-Sijistânî penyusun kitab Hadis dalam bentuk sunan, al-Intifấ bi Julud al-Sibâ' karya Muslim ibn alpenyusun kitab Hadis sahih, al-Shalâh yang disusun oleh salah satu guru al-Bukhârî yaitu Abû Nu'aym alFadhl ibn Dukayn al-Kûfî (219 H), dan karya Abû 'Abd Allâh Muhamammad ibn Nashr al-Marwazî al-Syâfi î̀ (294 H), al-Qirâah Khalf al-Imâm dan Raf al-Yadayn fi al-Shalâh karya al-Bukhârî, dan Ibn Hibbân menulis Shifah al-Shalâh. ${ }^{40}$

\section{Penutup}

Berangkat dari penjelasan di atas, dapat disimpulkan bahwa periwayatan Hadis sekaligus pembukuannya lebih didominasi oleh kepentingan fikih dari pada kepentingan periwayatan Hadis. Hal ini telah dimulai sejak masa sahabat sampai pada puncak pembukuan Hadis pada abad ke III dan IV $\mathrm{H}$ yaitu penyusunan kitab Hadis yang disepakati oleh hampir seluruh umat Islam sebagai kitab Hadis standar Shahîh al-Bukhârî, Shahîh Muslim, Sunan Abî Dâwûd, Sunan al-Nasầî, Sunan al-Tirmidzî, dan Sunan Ibn Mâjah.

Beberapa faktor yang mendukung dominasi fikih dalam periwayatan dan pembukuan Hadis ini di antaranya adalah adanya orientasi fikih dalam meriwayatkan Hadis sejak masa sahabat, formalisasi madrasah fikih, dan pengarusutamaan fikih dalam pembukuan Hadis. Ditambah lagi dengan adanya temuan bahwa pembukuan kitab Hadis karya alBukhârî dan Muslim berdasarkan fakta sejarah adalah untuk menguatkan ortodoksi Sunnî dan menjadikannya sebagai common language dalam diskusi-diskusi Hadis di kalangan sarjana-sarjana fikih empat mazhab. []

\section{Pustaka Acuan}

'Asqalânî, al-, Ibn Hajar, Hady al-Sârî, Riyâdl: Maktabah al-Malik Fahd al-Wathanîyah Atsnầ al-Nasyr, 2001.

\footnotetext{
${ }^{39}$ Ja'far al-Kattânî, al-Risâlah al-Mustathrafah, h. 40-43.

${ }^{40}$ Ja'far al-Kattânî, al-Risâlah al-Mustathrafah, h. 43-44.
}

\section{Risâlah, 1995.}

Abû Syuhbah, Muhammad ibn Muhammad, al-Wasîth

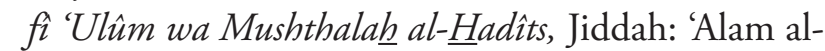
Ma'rifah, t.th.

-.---.----, Muhammad ibn Muhammad, Fî Rihâab al-

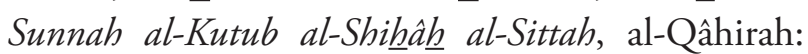
Majma' al-Buhûts al-Islâmîyyah, 1995.

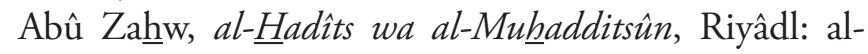
Ri'âsah al-Tsaqâfah li Idârât fî al-Buhûts al-'Ilmîyah wa al-Iftầ wa al-Da'wah wa al-Irsyâd, 1984.

Al-Sha'îdî, Hasan Fawzî Hasan, Al-Manhaj al-Naqdî̀ ind al-Mutaqaddimîn min al-Muhadditsîn wa Athar Tabâyun al-Manhaj (Tesis: Jâmi'ah 'Ayn Syams, 2000).

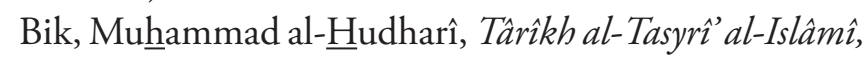
Bayrût: Dâr al-Kutub al-Islâmîyah, 1994.

Brown, Jonathan, The Canonization of al-Bukhârî and Muslim: The Formation and Function of the Sunn Hadîth Canon, Leiden: Brill, 2007.

Dimasyqî, al-, Ibn al-'Imâd Syihâb al-Dîn Abû al-Falâh

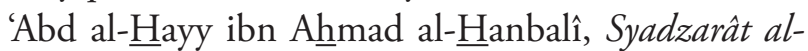
Dzahab fî̀ Akhbâr Man Dzahab, Bayrût: Dâr Ibn Katsîr, 1986.

Dzahabî, al-, Tadzhîb Tahdzîb al-Kamâl fî Asmầ al-Rijâl,

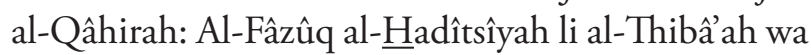
al-Nasyr, 2004.

-.---.-----, Siyar A'lâm al-Nubalâ, Bayrût: Mu'assasah al-Risâlah, t.th.

Fawzî, Ibrâhîm, The Documentation of Sunnah and Hadîth, London: Riad el-Rayyes Books Ltd., 1995.

Ghazâlî, al-, Abû Hâmid, al-Mustashfâ min 'Ilm al-Ushûl, Bayrût: Dâr al-Fikr, t.th.

Hâzimî, al-, Abû Bakr Muhammad ibn Mûsâ, Syurûth A'immat al-Khamsah, Bayrût: Dâr al-Kutub al'Ilmîyah, 1984.

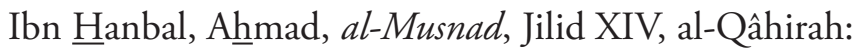
Dâr al-ㅂadîts, 1995.

Ibn ㅂazm, Abû Muhammad, al-I $\underline{h} k \hat{a} m$ fì Ushîl alA $\underline{h} k \hat{a} m$,Mesir: Mathba'ah al-'Ashimah, t.th.

Jazarî, al-, Majd al-Dîn Abû al-Sa'âdât al-Mubârak ibn Muhammad ibn al-Atsîr, Jâmi' al-Ushûl fî A $\underline{\text { had }}$ îts alRasûl, tahqî̀: 'Abd al-Qâdir al-Arnẩ ûth, t.t: Makta-

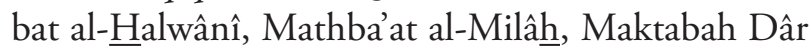
al-Bayân, 1969.

Kâfî, Abû Bakr, Manhaj al-Imâm al-Bukhârî fî Tashhîh $\underline{h}$

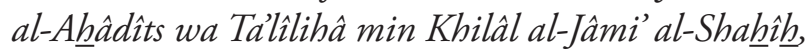
Bayrût: Dâr Ibn $\underline{\text { Hazm, } 2000 .}$

Kattânî, al-, Ja'far, al-Risâlah al-Mustathrafah li Bayân Masyhûr Kutub al-Sunnat al-Musyarrafah, Bayrût: Dâr al-Kutub al-'Arabîyah, 1995.

Khathîb, al-, Muhammad 'Ajjâj, Ushîl al- 
'Ulûmuh wa Mushthalahuh, Bayrût: Dâr al-Fikr, 1989.

Maqdisî, al-, Abû al-Fadhl Muhammad ibn Thâhir, Syurûth al-A'immat al-Sittah, Bayrût: Dâr al-Kutub al-'Ilmîyah, 1984.

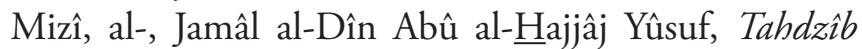
al-Kamâl fî Asmâ al-Rijâl, Bayrût: Muassasah alRisalah, 1983.

Qinnawjî, al-, Abû al-Thayyib al-Sayyid Shiddîq Hasan

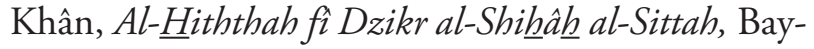
rût: Dâr al-Jayl, t.th.

Râmahurmuzî, al-, Al-ㅍasan ibn 'Abd al-Rahmân, alMuhaddits al-Fâshil bayn al-Râwî wa al-Wầî, Bayrût: Dâr al-Fikr, 1971.

Sakhâwî, al-, Syams al-Dîn Abu al-Khayr Muhammad ibn 'Abd al-Rahmân, Fath al-Mughith bi Syarh Alfiyah al- Hadîts, Riyâdh: Dâr al-Minhâj, 2007.

Schacht, Joseph, The Origins of Muhammadan Jurisprudence, Oxford: Oxford University Press, 1979.
Sibâî̀, al-, Mushthafâ, al-Sunnah wa Makânatuhâ fì alTaSyrî̀ al-Islâmî, Bayrût: Al-Maktab al-Islâmî Dâr al-Warrâq li al-NaSyr wa al-Tawzî̀, t.th.

Suyuthî, al-, Jalâl al-Dîn, Tadrîb al-Râwî fî̀ Syar $\underline{h}$ Taqrî̀b al-Nawawî, Bayrût: Dâr al-Kutub al-'Ilmîyah, 1996.

Syahrâzûrî, al-, Ibn al-Shalâh, Muqaddimah ibn al-

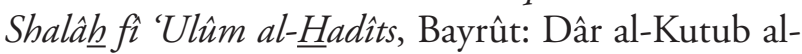
'Ilmîyyah, 1995.

Syîrâzî, al-, Abû Ishhâq, Thabaqât al-Fuqahầ, Bayrût: Dâr al-Râ'id al-'Arabî, 1970.

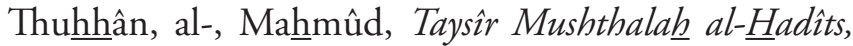
Kuwait: Markaz al-Hudâ li al-Dirâsât, 1984.

Zahrânî, al-, Muhammad ibn Mathar, Tadwîn al-Sunnah al-Nabawîyah Nasy'atuh wa Tathawwuruh min al-Qarn al-Awwal ilâ Nihâyah al-Qarn al-Tâsi' alHijrî, Madinah: Dâr al-Khudhayrî, 1998. 
108 Ahkam: Vol. XII, No. 2, Juli 2012 